\title{
Appropriate Bereavement Practice After the Death of a Native American Child
}

\author{
Joanne Cacciatore
}

\begin{abstract}
Native Americans and other minorities are statistically overrepresented in the thousands of infants and young children who die every year. Many of these deaths are unpreventable, sudden, and unexpected. Unique rituals and beliefs affect the way Native American families respond to these types of deaths. This paper is a guide for social workers and other caregivers. It examines best practices for culturally competent care and conveying respect for the Native American family. It is vital for social workers to educate, support, and advocate for families of culture in an aware, but not presumptive, style that allows reconciliation between two very different cultures. A case example is provided to illustrate important implications for culturally competent care when a child dies.
\end{abstract}

Cross-cultural training can either promote assimilation of the cultural outsider and reject indigenous approaches, or it can seek to promote integration. (Berry, 1989, p. 201)

$\mathrm{M}$ any multicultural textbooks openly discuss migration, sociopolitical controversies, gender roles, and family structures in the cultural context. However, there is little exploration into how culture affects the way a person or family deals with death, particularly the death of a child. The experience of death within the family system is common across cultures. Yet, the expressions of grief and ritualization are often very different. Thus, an individual's cultural identity should be carefully assessed when dealing with a grieving family. Parental grief spawns a subset of characteristics that seems to traverse culture. The death of a child is acknowledged in many cultures as one of the worst human experiences (Cacciatore, 2007; Kubler-Ross, 1978). This paper presents a case study in how social workers can enrich their understanding of culture, while attending competently to the unique needs of Native American families experiencing the death of a child.

As a result of shifting demographics in the United States, federal and state policy makers, as well as higher education institutions, are becoming increasingly concerned with ensuring cultural com- petency (Galambos, 2003), which is defined as "a set of congruent behaviors, attitudes, and policies that come together in a system, agency or among professionals and enables that system, agency or those professionals to work effectively in cross-cultural situations" (Cross, Bazron, Dennis, \& Isaacs, 1989, p. 22). Yet, institutions often fail to provide "appropriate support and intervention for families of color, families of the poor, and immigrant families. These family norms and values are different and therefore remain peripheralized, invalidated, and pathologized ... or worse, invisible" (McGoldrick, 1998, p. 75).

Cross et al. (1989) recommend essential elements to sensitive practice with families of culture wherein the system would value diversity, engage in cultural self-assessment and self-awareness, and support adaptations to diversity. The authors suggest these values should permeate every level of an agency, including policy (p. 8). Schlesinger and Devore (1995) suggest the "conscious use of self is at the core of social work technique, enabling workers to be aware and take responsibility for their own emotions and attitudes" (p. 58). Weaver (1999) found in working with Native Americans, "humility and a willingness to learn" were of the utmost importance, and she suggests social workers abandon "academic arrogance" (p. 222). She recommends social workers strive to "understand the contemporary realities of specific Native 
American clients" and learn to tolerate silence as an intervention strategy (p. 217).

A family with strong ethnic values and mores may react differently to issues related to traumatic death. Developing a sense of cultural competence is, therefore, the cornerstone of culturally sensitive care. The Code of Ethics of the National Association of Social Workers (NASW, 1999) identifies the need for specific competencies regarding cultural competence and social diversity, including the need to "have a knowledge base of their clients" cultures and be able to demonstrate competence in the provision of services that are sensitive to clients' culture and to difference among people and cultural groups" (1.05). An individual's culture includes many complex factors, including country of origin, ethnicity, family structure, gender, religion, historicity, and other more ambiguous elements that help define identity. Additional anecdotal differences in expressions of grief may include the experience of pain, the nature of the relationship with and attachment to the deceased, the person's communication style, the person's beliefs about the cause of death, attitudes toward the doctors or other health care providers, and treatment they expect and receive (Cowles, 1996; Davidhizar \& Giger, 2004; Kalish, 1980; McGoldrick, Almedia, \& Hines, 1991; McGoldrick, Garcia-Preto, \& Giordano, 2005).

\section{Native American Culture}

There are more than 550 American Indian and Alaskan Native tribes in North America (Ortiz, 2002). The federal government officially recognizes more than 300 of those tribes (Nichols, 1998). About 39\% of Native Americans in North America live on tribal land, and about $61 \%$ live in urban areas, where some degree of acculturation is likely (Harvard Project, 2004). There is vast heterogeneity among Native American tribes. Garrett and Garrett (1994) have identified degrees of acculturation along a continuum, defining traditional as a state wherein individuals may or may not be fluent in the English language, but generally prefer to speak, as well as think, in their native language. They may also "hold traditional values and beliefs while practicing only traditional tribal customs and methods of worship" (Garrett, Tlanusta, \& Eugene, 2000, p. 3).

Traditional Native American tribes are rich with their own cultural responses and rituals after death. For example, Clements, Vigil, Manno, \& Wilks (2003) - in observing Navajo, or Dineh, traditions-describes death rites as an elaborate four-day preparation and burial of the body in which families actively mourn and dispossess their personal belongings: "The deceased's hair is tied with an eagle's feather to symbolize their return home ... and the deceased was buried in the family's hogan" (p. 23). On the fourth day postmortem, relatives cleanse themselves thoroughly, as if washing away the need for further mourning. After the fourth day, mourners do not speak the name of the deceased, fearing that doing so will summon back the person's soul. In Hopi culture, life is cyclical, from birth to death to rebirth, with "each person [as a] duality of soul and body" (Leming \& Dickinson, 1990). Upon death, the deceased are offered new names to carry into the afterlife. The Sioux Indians bury a traditional hatchet in the casket to ward off demons.

Some American Indian tribes have strong feelings about death. Nature metaphors are palpably integrated into their lives as they incorporate these images into stories of death and the afterlife. For example, the butterfly is used as a symbol of everlasting life and can be a comfort to the family facing death (Cherry, 1997). The Wilik-wilik Waashaashut, or Butterfly Dance, is a ritual representing the transformation of the caterpillar into a butterfly. Most believe the spirit lives on even after death, and they are more accepting of the death and dying process than Western culture. Black Elk teaches Lakota followers the first and most important peace comes within the soul of humans when they realize their relationship, their oneness with the universe and all its powers. And at the center of the universe dwells Wakan-Tanka (God), residing within each person (Rice, 1991).

American Indians often rely on their interpersonal relationships for social, emotional, spiritual, and sometimes financial support during a crisis. Tribal hierarchy, medicine men, and traditional American Indian garb, including healing feathers and prayer beads, may play an important role for family and tribal members. Many American Indian tribes accept their unique processes of ritualization as a way to live in sacredness (Ramirez, 1999), offering a coping style that is congruent with their system of kinship and sense of spirituality.

Communicating with a Native American family may be challenging for a person who lacks knowledge of their culture. The heritage-consistent Native American values listening. Long periods of silence and an indirect style by American Indian clients can perplex caregivers. Some professionals may mistakenly view the silence, use of metaphors, and indirectness as resistance or lack of understanding (Sutton \& Nose, 1996; Weaver, 1998). Native Americans may avoid direct or sustained eye contact and may not demonstrate affect, even during a crisis. Thus, effective communication becomes the very foundation from which the relationship between the worker and client progresses (Napoli, 1999; Sutton \& Nose, 1996; Weaver, 1998).

\section{In many Native American tribes, soul- searching, meditation, and ancestor prayer may play a role in providing an altered state of consciousness that is necessary for some to discover meaning in the loss.}

American Indians perceive time as cyclical rather than linear (Herring, 1990). Time is not organized in structured calendars, but rather it is controlled by nature, seasons, and individual rhythm. This could affect how the family responds to a crisis situation and their ability to seek outside support or assistance after a child's death. Burial rituals often take more time and are an integral part of their Native American culture. Families are unlikely to rush their way through the burial or cremation process. In addition, an autopsy is usually forbidden in the Sovereign Nation. Many tribes also prohibit postmortem contact with the deceased, and some tribes discourage organ donation. 
However, it is important not to rule out options such as the autopsy, organ or tissue donation, or the opportunity to hold or see the child who died simply because the family is American Indian. Depending on the degree of acculturation, some families may not adhere to the social proscriptions of the tribe. So whereas it is important to be aware of their general beliefs, social workers and other caregivers are obligated to understand the client, allowing for differences based on the individual, family system, and circumstances (Saleebey, 2001).

\section{Culture, Mourning, and Child Death}

Across cultures, common experiences after a child's death-such as disconnectedness from friends and family, abandonment of faith, isolation, and guilt-can create multiple dilemmas for families. Shaking their belief in the order of the world, this type of traumatic loss often fosters a sense of total helplessness. Spirituality can play an important role, across cultures, in helping families to heal and discover meaning after a child's death (Frankl, 1998). In many Native American tribes, soul-searching, meditation, and ancestor prayer may play a role in providing an altered state of consciousness that is necessary for some to discover meaning in the loss. The social worker can do the following to encourage and facilitate an open dialogue that enables, empowers, and engages Native American families:

- Ask permission to act.

- Ask about their rites and rituals, culture, religion, and belief system. Caregivers can humbly admit their own lack of knowledge, becoming willing students and helpers.

- Ask for their story. Give them a voice. Enable them to tell and retell their story within their own cultural understanding and context.

- Ask family members what ongoing needs they have, and try to facilitate those needs.

- Finally, be aware of and model their nonverbal communication styles back to them. For example, if working with heritage-consistent, Native American family members who avoid sustained eye contact, do not attempt to make eye contact. Instead, respectfully adapt to their communication style.

McGoldrick et al. (1991) identified five questions that professionals should consider of particular importance to families of culture after a traumatic death:

1. What are the culturally prescribed rituals for managing the dying process, the deceased's body, the disposal of the body, and commemoration of the death?

2. What are the family's beliefs about what happens after death?

3. What does the family consider to be an appropriate emotional expression and integration of the loss?

4. What does the family consider to be the gender rules for handling the death?

5. Do certain types of death carry a stigma (e.g., suicide or stillbirth), or are certain types of death especially traumatic for that cultural group (e.g., homicide or death of a child)?

This dialogue builds a trusting relationship in which a true sense of cultural competence is achieved. In the case of child death, it is even more important that the professional approach each family with sensitivity to cultural context as well as sensitivity to the needs of a new cultural context: families traumatized by a child's death. With respect to the culture of grief, there are three distinct roles that may be helpful across cultures.

The first is an educational role, or family education, which serves to introduce grieving families to their options. It provides the opportunity to engage in rituals that other grieving parents have found to be helpful, such as holding the child who died, collecting mementos, or calling upon spiritual leaders to hold prayer ceremonies. Caregivers should take this opportunity to educate the family about institutional processes such as the autopsy procedure (if applicable) or vital records protocol, grief responses, community resources, and follow-up care. The second, psychosocial presence, is often represented nonverbally and communicated by remaining available and present with the family in the face of profound grief. Nel Noddings defines ethical caring as a relationship that flourishes through mutuality, understanding, and compassion (Flinders, 2001). Here, it becomes important to demonstrate respect for the family's culture, which includes facilitation of culturally competent rituals, support of the family system, and empathic communication. Finally, Native American families may need social work professionals to act as advocates on their behalf, particularly when the family is unfamiliar with local laws.

The following case study from the author's own experience is offered as an example of the three roles of the social worker as family educator, psychosocial supporter, and advocate. (Note: All names have been changed.)

\section{Case Study in Cross-Cultural Mourning}

The call came in early on Saturday morning, and there was an urgency in the medical examiner's voice. As the family liaison for the county coroner's office, I turned my car around and headed for downtown. I arrived at the medical examiner's office to find the medical examiner waiting for me.

"Why is this one so urgent?" I inquired.

"The family rejected the autopsy .... They're from the reservation. This is a real problem for us," the medical examiner replied. "It is a cultural taboo, I suppose."

I responded, "Well, don't do the autopsy."

Then I remembered the law. An autopsy must be performed on all sudden child deaths in our state. The only exception is when the death actually occurs on the Sovereign Nation. Although this child lived on the Sovereign Nation, he was transported by helicopter to a local children's hospital, where he later died. I began to realize the seriousness of this case.

I approached the family in the parking lot, walking toward them slowly. There were two middle-aged couples and a very young couple standing in close proximity. A middle-aged man, Henry, whom I later identified as the paternal grandfather, stepped forward, setting himself clearly apart from the group. $\mathrm{He}$ was directing me to communicate with him and no one else. Thus, I introduced myself to him only, not approaching or making eye contact with any other family member. I invited him inside the county offices, and he brought his family inside. I offered Henry water and tissues for his family, and I assured him that I would act as their advocate, doing my best to help.

As I continued to directly address only Henry, I expressed my 
recognition of their tragedy.

"Henry, I'm just so very sorry. I cannot imagine how difficult this must be for you and your family," I said. Then, I asked in a very quiet voice, "Can you tell me your story?"

Henry explained that his grandson, Joseph, had been a healthy, thriving 18-month-old. He became ill very suddenly, and after the onset of a high fever, the parents consulted with the medicine man. When the medicine man's attempts to heal Joseph were unsuccessful, Henry urged the young parents to take him to the closest medical center. Following the advice of the grandparents, they took Joseph to the clinic. (I noticed that, as Henry told the story, he avoided any direct eye contact. This behavior was contrary to other interactions I've had with families in crisis. Still, taking his lead, I made a conscious effort not to look directly in his eyes. There was also significant distance, about four feet, between Henry and myself during this time. The other members of the family were sitting in chairs behind him. No one else in the family addressed me or made eye contact at this point.)

Shortly after their arrival at the medical center, Joseph had a seizure. Ill equipped to handle a pediatric emergency, the medical team airlifted him to the children's hospital, where, despite valiant efforts to save him, he was pronounced dead a few hours later. Mystified, the attending physicians sent Joseph's body for autopsy and informed the family, who then began to protest the procedure.

As Henry told the story, the other family members began to quietly cry, huddling in the corner of the couch, holding on tightly to one another.

"We don't permit autopsies where we come from. It interferes with the ascension of the spirit. It is a violation of our customs," he insisted.

Empathically, I reassured him that I would be their advocate, and I took a few minutes to explain the usual protocol at the medical examiner's office.

"Henry, I will do my best to explain this to the doctor. May I leave you for a few minutes and talk to the doctor," I asked, "and I'll return in about 15 minutes?"

With his consent, I went into the back office, where only one medical examiner worked on Saturday. I talked to her about the family and reinforced the need to respect their cultural beliefs. Understanding the dilemma, she agreed to work on other solutions.

"If we can start with x-rays and laboratory tests, we may be able to find the cause of death without having to autopsy. Will they allow this?" she inquired.

Back in the waiting room, Henry agreed to this option. Together in silence, we awaited the answer that would come two hours later. Occasionally, Henry led his family in native prayers, spoken softly under their breath. I felt more comfortable as my understanding of their culture was deepening. I remained with them the entire time, sitting on the other side of the room and remaining silent.

The medical examiner asked to see me through the security window partitioning the waiting area from the back offices. This would be the first time the family members made eye contact with me. Henry looked at me and I looked back.

"I'll be right back," I said softly, excusing myself to the back office.

The medical examiner had found the cause of death without needing to perform an autopsy.
"What happened to him?" I asked. She explained that Joseph had developed an intestinal obstruction that became infected. He died of sepsis.

Both the medical examiner and I went into the waiting room to inform the family. I spoke directly to Henry and, as the medical examiner listened, his head dropped. The family began to cry as I explained the cause of Joseph's death. Henry remained emotionless.

I said, "I’m just so sorry, Henry. Do you have any questions that I can answer for you?"

"No," he said quietly.

"Henry, would you like to see Joseph?" I asked.

From the corner of my eye, I saw Joseph's young mother look up, wide-eyed. She said nothing.

Henry responded, "No, no, no. We don't want to see him. We must not."

There was complete silence in the room. Concerned that I may have offended Henry, I quickly apologized, explaining that I was unfamiliar with their beliefs. I wanted to give them some time alone as a family, so I asked permission to leave. When I returned to the waiting room, Henry's wife immediately addressed me.

"Joanne, we want to see Joseph. We have decided to see him," she said.

Henry nodded in affirmation. I went into the back office immediately and prepared a small office for them to use. I made a bed out of an office desk, putting layers of blankets and pillows on it. I brought in enough chairs for everyone and dimmed the lights. I returned with Joseph's body a few minutes later, wrapped in a warmed blanket.

Henry quickly stood up and looked directly at me. He paused a moment, looked down at Joseph, and then gently he took him from my arms. His face softened. Everyone was quiet. Henry held Joseph in his arms and began to talk to him in their native language. He kissed his feet, his arms, and his cheeks. Within minutes, everyone became very emotional. Henry tied a sacred healing feather, used earlier that day by the medicine man, on Joseph's shirt, and then Henry passed the child to his wife. For more than two hours, each family member had a turn to say good-bye.

At one point, I went to leave, telling Henry I wanted to give them private time. He grabbed my arm and asked, "Please, stay with us." Two hours later, they said their final good-byes and, reluctantly, handed Joseph back into my arms.

The family waited for me in the parking lot. I expressed my sympathy again. I told them that I would be available any time they had a question or needed anything in the future. I thanked them for their patience and said my final good-byes. Joseph's young mother yelled out across the parking lot. I stopped at the door of the office and turned. She walked toward me, and the others followed. She wrapped her arms around me, began to cry.

"Thank you so much," she said over and over.

Her young husband came up behind her, embracing us both and began to cry, also thanking me. Then, one by one, the grandparents surrounded me in an embrace.

I learned how to be a student that day. I learned about patience and silence. I learned how to set aside my own beliefs to help clients. And the greatest teacher that day was a young boy named Joseph, whom I shall never forget. 


\section{Conclusion}

Every society has developed rituals around birth and death. Ritual is a powerful part of culture, hailed by some as the "antidote to powerlessness" (Miller, 1999). Culturally competent practice with Native American families requires both a willingness to learn about the others' culture and sensitivity to the importance of their expressions of culture within the larger community. Whereas cultural norms need to be considered after the traumatic death of a child, it is also very important to treat each person as an individual and each family as a culture of its own. Familial grief after a child's death is often so evocative there is likely to be no predictable template for coping, even from within traditional Native American or indigenous cultures.

Working toward an aware, but not presumptive, respect-based treatment intervention requires professionals to understand their communities. Social workers should take the time to become familiar with the primary cultures in their communities (Gray, 2004; Horn, 2005) and “assess a Native American client's level of acculturation rather than making assumptions based on the limited information offered by appearance or other personal characteristics" (Garrett et al., 2000, p. 3). The degree of acculturation can affect individual identification with their culture of origin, and thus choices about care should be related by the family instead of presumed by a social worker. With a diverse and ever-changing demography, it is vital for social workers to educate, support, and advocate for families of culture in an aware, but not presumptive, style that allows reconciliation between "two very different cultures" (Garrett et al., p. 5). By allowing bereaved parents to lead and instruct, the health care provider can give them a sense of control over their situation that may reduce poor psychological outcomes later.

\section{References}

Berry, J. W. (1989). The psychology of acculturation. In J. J. Berman (Ed.), Nebraska symposium on motivation: Cross-cultural perspectives (pp. 200-234). Lincoln: University of Nebraska Press.

Cacciatore, J. (2007). Effects of support groups on post traumatic stress responses in women experiencing stillbirth. Omega, 55(1), 71-91.

Cherry, R. (1997). Native American Mythology. Retrieved December 22, 2007, from http://www.insects.org/ced4/mythology.html

Clements, P., Vigil, G., Manno, M., \& Wilks, J. (2003). Cultural perspectives of death, grief, and bereavement. Journal of Psychosocial Nursing and Mental Health Services, 41(7), 18-26.

Cowles, K. (1996). Cultural perspectives of grief: An expanded concept analysis. Journal of Advanced Nursing, 23(2), 287-294.

Cross, T., Bazron, K., Dennis, B., \& Isaacs, M. (1989). Toward a culturally competent system of care: Monograph on effective services for minority children who are severely emotionally disturbed. Washington, DC: CASSP Technical Assistance Center, Georgetown University Child Development Center.

Davidhizar, R., \& Giger, J. N. (2004). A review of the literature on care of clients in pain who are culturally diverse. International Nursing Review, 51(1), 47-55.

Flinders, D. (2001). Nel Noddings. In J. Palmer (Ed.), Fifty modern thinkers on education: From Piaget to the present. London: Routledge.

Frankl, V. (1998). Man's search for meaning. New York: Washington Square.
Galambos, C. (2003). Moving cultural diversity toward cultural competence in health care. Health and Social Work, 28(1), 3-4.

Garrett, J., \& Garrett, M. (1994). The path of good medicine: Understanding and counseling Native Americans. Journal of Multicultural Counseling and Development, 22, 134-144.

Garrett, M., Tlanusta, P., \& Eugene F. (2000). Red as an apple: Native American acculturation and counseling with or without reservation. Journal of Counseling and Development, 78(1), 3-13.

Gray, L. (2004). An interview with modern day medicine man. Native American Times, V. XI, 38, 6 .

Harvard Project on American Indian Economic Development. (2004). Key Statistics about Native America: September 2004. Retrieved December, 28 2008, from http://www.ksg.harvard.edu/hpaied/documents/FactSheet-HPAIEDSept2004_001.pdf

Herring, R. (1990). Understanding Native American values. Counseling and Values, $34,134-136$.

Horn, K. (2005). Ethnocentrism ruins sun dance. Native American Times, 6(38), 6. Kalish, R. (1980). Death and dying: Views from many cultures. New York: Baywood.

Kubler-Ross, E. (1978). To live until we say goodbye. Englewood Cliffs, NJ: Prentice Hall.

Leming, M., \& Dickinson, G. E. (1990). Understanding death, dying and bereavement (2nd ed.). Philadelphia, PA: Harcourt College Publishers.

McGoldrick, M. (1998). Re-visioning family therapy. New York: Guilford Press.

McGoldrick, M., Almedia, R., \& Hines, P. M. (1991). Mourning in different culures. In F. Walsh \& M. McGoldrick (Eds.), Living beyond loss: Death in the family (pp. 176-206). New York: W. W. Norton.

McGoldrick, M., Garcia-Preto, N., \& Giordano, J. (2005). Ethnicity and family therapy (3rd ed.). New York: Guilford Press.

Miller, S. (1999). Finding hope when a child dies. New York: Simon \& Schuster.

Napoli, M. (1999). The non-Indian therapist working with American Indian clients: Transference-countertransference implications. Psychoanalytic Social Work, 6(1), 25-47.

National Association of Social Workers. (1999). Code of Ethics of the National Association of Social Workers. Retrieved October 28_, 2007, from http://www.socialworkers.org/pubs/code/code.asp

Nichols, R. (1998). Indians in the United States and Canada: A comparative history. Lincoln: University of Nebraska Press.

Ortiz, J. (2002). Tribal governance and public administration. Administration and Society, 34(5), 459-481.

Ramirez, R. K. (1999). Healing through grief. Urban Indians reimagining culture and community. American Indian Culture and Research Journal, 22(3), 305-333.

Rice, J. (1991). Black Elk's story: Distinguishing its Lakota purpose. Albuquerque: University of New Mexico Press.

Saleebey, D. (2001). Human behavior and social environments. New York: Columbia University Press.

Schlesinger, E., \& Devore, W. (1995). Ethnic sensitive social work practice: The state of the art. Journal of Sociology and Social Welfare, 23(1), 29-58.

Sutton, C. T., \& Nose, M. A. (1996). American Indian families. In M. McGoldrick, J. Giordano, \& J. K. Pearce (Eds.), Ethnicity and Family Therapy (pp. 31-41). New York: Guilford Press.

Weaver, H. W. (1998). Indigenous people in a multicultural society: Unique issues for human services. Social Work, 43(3), 203-211.

Weaver, H. W. (1999). Indigenous people and the social work profession: Defining culturally competent services. Social Work, 44(3), 217-225.

Joanne Cacciatore, PhD, MSW, FT, is fellow in thanatology, School of Social Work, College of Public Programs, Arizona State University. Correspondence regarding this article can be addressed to the author at Joanne.cacciatore@asu.edu or ASU West Campus, CHS/SW, 4701 W. Thunderbird Rd., Glendale, AZ 85306.

Manuscript received: November 7, 2007

Revised: February 11, 2008

Accepted: February 12, 2008 